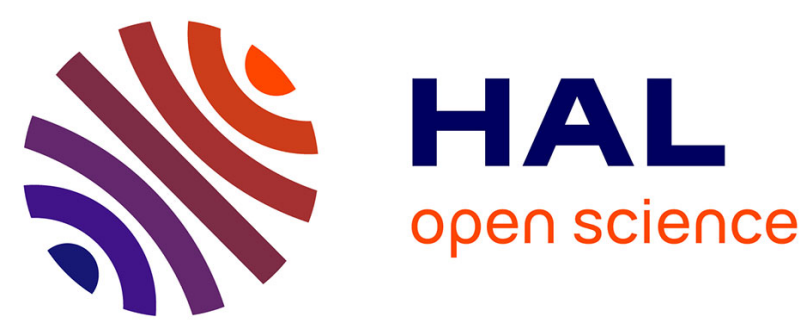

\title{
The governance of Higher Education Systems: A public Management Perspective
}

\author{
Ewan Ferlie, Christine Musselin, Gianluca Andresani
}

\section{To cite this version:}

Ewan Ferlie, Christine Musselin, Gianluca Andresani. The governance of Higher Education Systems: A public Management Perspective. Ewan Ferlie; Catherine Paradeise; Emanuela Reale; Ewan Ferlie; Ivan Bleiklie. University Governance: Western European Comparative Perspectives, Springer, pp.1 19, 2009, 9781402086373. 10.1007/978-1-4020-9515-3_1. hal-02906118v1

\section{HAL Id: hal-02906118 \\ https://hal-sciencespo.archives-ouvertes.fr/hal-02906118v1}

Submitted on 26 Jul 2021 (v1), last revised 10 Dec 2021 (v2)

HAL is a multi-disciplinary open access archive for the deposit and dissemination of scientific research documents, whether they are published or not. The documents may come from teaching and research institutions in France or abroad, or from public or private research centers.
L'archive ouverte pluridisciplinaire HAL, est destinée au dépôt et à la diffusion de documents scientifiques de niveau recherche, publiés ou non, émanant des établissements d'enseignement et de recherche français ou étrangers, des laboratoires publics ou privés.

\section{(1)(1) $\$(0)$}

Distributed under a Creative Commons Attribution - NonCommercial - ShareAlikel 4.0 


\title{
The governance of Higher Education Systems: A public Management Perspective
}

\author{
In : University Governance: Western European Comparative Perspectives. 2009 \\ ISBN : 9781402086373
}

Prof Ewan Ferlie, CPSO, School of Management, Royal Holloway University of London Ewan.ferlie@rhul.ac.uk

Dr Christine Musselin, CSO, Sciences Po and CNRS, Paris. c.musselin@cso.cnrs.fr

Gianluca Andresani, University of Hull, g.andresani@hull.ac.uk

\section{The 'Steering' of Higher Education Systems : A Public Management Perspective'}

European higher education systems experienced major changes and many publications have already proposed to assess and analyse this evolution. But looking at the state of the art on this issue, as will be done in the first section of this introduction, it appears that none adopted a public management perspective and considered wider patterns of public sector 'reforming' and how they have been applied to higher education systems within the European Union. Although most higher education systems in Europe, but also in the US, are publicly funded, admit the highest share of students and, by contrast with the US benefit from higher reputation than many private institutions, higher education has rarely been studied as a public policy or management topic so has not been one of the traditional areas covered by generic political scientists or public management scholars.

'Bringing in' more generic concepts from political science and public management more fully into the study of higher education institutions is a promising avenue to explore academically and may re-invigorate the study of higher education institutions. Often the higher education sector is seen as a 'stand alone' sector which is not directly or easily comparable with other types of organisation, even within the public sector. The ideology of academic and

\footnotetext{
1 The three main points developed in this introduction are in a large part reproduced from the chapter "The 'Steering' of Higher Education Systems: A Public Management Perspective', the three authors wrote for HELF (Higher Education Looking Forward), a Forward look project of the European Science Foundation (ESF). It is reproduced here with the agreement of the ESF (Ferlie, Musselin and Andresani, 2007). The papers written for this HELF project will be edited in a special issue of the journal Higher education (forthcoming in 2008).
} 
institutional autonomy as described by Merton which is so well developed within the higher education sector supports this sectoralist approach. There may be some evidence to support this notion of difference even at the organisational level: for example, UK Universities retain more self direction and less central control than some other UK public sector settings, such as the National Health Service (the very name describes a national rather than a local service). Yet at a more fundamental level, the organisational similarities with other professionalized public sector settings such as health care are more important than the differences: European Universities are largely dependent on the state for financing; the state is concerned to regulate their behaviour as they influence citizens' life chances significantly; they contain a mix of professional and bureaucratic elements and they operate within strongly structured institutionalised fields. There are many fundamental similarities with other public service settings such as health care. Within organisational analysis, they fit well with the more general archetype of the professionalized organisation developed by Mintzberg (1979).

Part of this wider approach enables us to reconnect the micro world of higher education institutions with developments within the macro world of the state. In this introduction we will also argue that there has been a move away from the traditionally Mertonian concepts of higher education autonomy: the state is now seeking to shape higher education systems more actively. The use of more generic perspectives is evident in some recent studies of higher education (Hood et al, 2004; Reed, 2002; Maassen and Stensaker 2005): we here add to it through an analysis of system level steering which draws on two distinct narratives of public management reforming: the New Public Management on the one hand and the Network Governance narrative on the other.

Within this conceptual framework, this book focuses on the transformation of the "steering" of higher education systems in seven European countries: France, Germany, Italy, the Netherlands, Norway, Switzerland and the United Kingdom. It is the first publication issued from a research project called SUN (Steering UNiversities) undertaken by the authors and other colleagues within PRIME ${ }^{2}$, a network of excellence funded though the EU.

By 'steering', we here mean the externally derived instruments and institutional arrangements which seek to govern organisational and academic behaviours within higher education institutions. They are usually but not always emanating from the state. This book will highlight the role of the state in seeking to shape increasingly strategic higher education systems towards national policy goals through the use of reformed 'steering' systems.

We will therefore argue that the state increasingly seeks to govern and 'steer' higher education systems as it does for its other publicly funded services. These steering patterns vary considerably from one European nation state to another, reflecting attachment to alternative narratives, conditions of path dependency and localised reform trajectories

More precisely, we will analyze these national situations and how they evolved since the 80s in the light of the two main narratives of public management reform mentioned above which apply to higher education subsystems as well to other public service subsystems. Before describing them and looking at how they can be applied to higher education, this introduction will start with a brief overview of the research previous led on the transformations of higher

2 Within the $6^{\text {th }}$ framework, the EU developed new instruments to foster research activities at the EU level. Networks of excellence were one of these instruments. PRIME has been selected among the many projects which applied for EU funding on this basis. It concerns more than 40 research groups in Europe working on Policy for Research and Innovation in the Move towards the European research area. 
education systems and highlight how the recent changes they experienced can be related to broader evolutions of European public services.

\section{How higher education governance has been analyzed}

During the $20^{\text {th }}$ century, higher education was generally studied as a specific sector of state intervention. Education and research being considered as public goods, the recourse to specific policies and instruments by public authorities was justified.

On the one hand, an important part of the literature (developed in 1.1) focused on higher education public policies in terms of reforms and decision-making, in order to qualify (and also often prescribe) what the role of the state should be on this specific domain. Within this range of the literature, one conception long prevailed. According to it state intervention is expected to be limited: the understanding of science as an autonomous sphere argued in favour of a "Republic of Science" (Polanyi 1962), which leaves steering and governance in higher education first of all in the hands of academics. But two alternative conceptions have more recently developed.

On the other hand, another part of the literature (addressed in 1.2) rather tried to identify the (collective) actors involved in the higher education sector, to describe the relationships they have one with another and to qualify the mode of regulation prevailing among them. Studying public policies and their content is then less important than discovering and understanding the policy network ${ }^{3}$ or the policy regimes ${ }^{4}$ producing them. These approaches much more focus on the description of higher education systems and are more interested in routine or day-today practices and relationships within them.

\subsection{Three main conceptions of higher education governance and higher education policies}

When looking at higher education public policies and state intervention in this sector, a first conception is strongly related to the Mertonian sociology of sciences which considers that the role of the state, if any, is to ensure the autonomy of higher education (or science more precisely). The higher education subsystem is here characterised by a high degree of autonomy and insulation from governmental steering ${ }^{5}$, despite its dependence on the public purse. Some authors characterize this as "policy for science" (Rouban 1988) or "regulation by the community" (Paradeise 1998). The German idealist tradition built around the Humboldtian model, and the American functionalist sociology of professions ${ }^{6}$ both idealised

3 The notion of policy network is used here in its descriptive heuristic meaning (following Rhoades and Marsh for instance) and not as an alternative model to pluralism and neo-corporatism to think the state society relationships (as suggested by Lehmbruch 1995 for instance).

$4 \quad$ As defined by I. Bleiklie (2000: 54): "the network of patterns of influence that are particular to a policy area or an entire polity".

5 At the national and at the international level: G. Mallard (2006) for instance shows how some scientists in the US claimed an academic international control over nuclear research after the second World War, but finally lost their battle.

6 We agree with the distinction by I. Bleiklie, R. Hostaker and A. Vabo (2000) between the idealist and the functionalist approaches but in this paper we want to stress their convergent conceptions about the role of the state. 
this conception. Academics are described as producers, users and owners of an esoteric knowledge whose quality or costs can not be assessed or controlled by "profanes" (public authorities, members of the civil society, etc.). Academics therefore receive a monopoly from the state to exercise their function. The state accepts to protect them from the external influences, as long as the academic community implements norms, values and practices preventing an abusive use of their knowledge. This conception relies on an ideology of academic freedom and strong faculty control over key work practices in both domains of research and teaching. This has long been the dominant analytical and normative framework.

The British higher education system until the end of the seventies provided a good example of this conception: the state allocated a public budget to the UGC (University Grant Committee), a purely academic body which then distributed it to highly collegial higher education institutions (Halsey 1992, Shattock 1998, Kogan and Hanney 2000).

One result of this perspective is that organisational and governance reforms are conceived as endogenous to an autonomous higher education subsystem and not as related to wider public policy goals or reform processes.

A second conception attributes to the state an important role in mediating the interests of the society and orienting the development of HE. The state is expected to drive scientific activities, to command and control them. This happens when there is increased suspicion of the performance of traditional publicly funded service systems by publics, politicians and policy makers. The higher education system, like any other, is vulnerable to capture by producer dominated interest groups (here academics and scientists) so that government may need to exercise its countervailing power to counter excessive endogeneity or to champions powerless consumers. From this perspective, higher education is no different from other publicly funded services (e.g. health care; criminal justice) where the state may put pressure on publicly funded providers to meet broad public policy goals (for example) to cut costs, improve quality or ensure social equity (Van der Meulen 1998).

The role of the state is also likely to be stronger when the higher education subsystem become bigger, more expensive, politically more visible and economically more strategic. This is what occurred in many countries over the last decades. As the higher education system massifies, so these external and governmental pressures on the higher education subsystem may be expected to increase. Within the knowledge based economy, the connection between the higher education institution subsystem and policy goals of economic growth become sharper. The invention and diffusion of new science based technologies (e.g. recent emphasis on clinical genetics technologies) which brings together university science, venture capital, hi tech forms and government is a critical arena. The interventionist state may often be more concerned with Big Science than wider higher education policies and this has led to an emphasis of the role of public authorities in big equipment etc.

A third conception has stressed the role of the market in higher education governance (Dill 1996). The idea that teaching and research may be commodities rather than public goods gained attention and developed while academic freedom has been redefined and the image of the scientist protected from the world in an ivory tower condemned ${ }^{7}$. In the literature on higher education governance this is most of the time presented as a rupture with the

7 This includes politicians and university reformers but also the tenants of the "strong programme" (among many others: Bloor 1976, Latour 1987, Lynch 1993...) who fight against the idea of science as a different activity and of scientists as a group outside the society. 
"command and control" conception and as a drift from interventionist to "evaluative" governance (Neave 1986 ; Van Vught 1989 et 1995 ; Neave et van Vught 1991 et 1994): from dirigisme to supervision, from ex-ante control to ex-post evaluation, from rules to regulation (Amaral, Meek and Larsen 2003). This conception therefore does not claim a reduction of the state but for a state expected to achieve one or both (depending on authors) of the following missions: stimulate the strength of market forces on the one hand but also detect, prevent or repair market failures on the other. The first mission would encourage students to start to behave more like consumers. Such consumer pressure would in turn act as a helpful spur to greater quality and competition among higher education institutions would increase. The role of public authorities is here to facilitate the development of a market and this may be difficult, given the weak market orientation of many higher education systems and lack of effective competition (historically there is no market entry or exit and strong planning systems). About the second mission, the state is expected to set and defend broad principles (equality of access for instance) and to intervene if threatened by the increase in market-forces.

Whatever the prevailing conception, the academic works interested in higher education public policies and the role of the state on this domain mostly focus on two types of issues. On the one hand, they describe the measures included in the reforms and qualify the nature of the change at which the objectives of these reforms are aiming (for instance: is this reform a move towards the evaluative state? Good examples of such approaches can be found in Goedegebuure et al. 1993, Teichler 2005a and 2005b). On the other hand, they consist in implementation analysis in line with the studies led first by L. Cerych and P. Sabatier (1986). Recent studies on the impact of the reforms led in Europe are representative of this perspective. The comparative study recently edited by B. Kehm and U. Lanzendorf (2006) on four European countries for instance relies on a powerful analytic scheme (see also de Boer, Enders and Schimank, 2007) aimed to describe and assess the degree of changes experienced by national higher education systems. This scheme ${ }^{8}$ distinguishes five major components (state regulation, stakeholder guidance, academic self-governance, managerial selfgovernance and competition for resources) and can thus provide a visual representation of change for each country and of the impact of the implementation of the reforms.

But, by contrast, few studies carefully reconstruct how such policies arrive on the agenda, the political entrepreneurs and the interest groups involved ${ }^{9}$, the way the problems are defined and constructed, how solutions are developed and the narratives attached to them (Radaelli 2000, Stone 1997). In brief, they rarely address the wider political economy of higher education 'reforming'.

\section{The study of higher education systems as policy networks}

Looking now at the literature which is interested in the description and understanding of higher education systems, it aims at qualifying the type of policy networks they are alike and at identifying the nature of the relationships within them.

These five components are very close to the mechanisms suggested by D. Braun and F.-X. Merrien (1999).

9 In their analysis of the transformation of the British higher education system, M. Kogan and S. Hanney (2000) provide an interesting analysis of what they call the "co-opted elite", i.e. mostly academics who are recognised as interlocutors by the political and ministerial actors and contribute to the definition of the forthcoming reforms. 
Most publications analysing how higher education systems work and are transformed, pay exclusively attention to the state-universities relationships. As a matter of fact the content of recent public policies most likely consist in reconfiguring the status, internal structures, governing bodies, field of responsibilities, decision-making processes, and scope of action of higher education institutions (Braun and Merrien 1999). Moreover, there are trends towards the devolution of more institutional autonomy to universities and the constitution of more governed, accountable and responsible institutions.

Nevertheless higher education systems, like other public sectors such as health and justice, have the specificity of consisting in institutions and a profession. However less attention is paid in the literature to how this affects the relationships between the state and the academic profession although in many European countries, public authorities may still have an impact on academic careers (cf. for instance Enders 1996 and 2001 or Musselin 2005), thus influencing the nature of the link developing between each academic and his/her institution ${ }^{10}$. Moreover, in some countries (like France, or Italy) the state has developed stronger relationships with the representatives of the academic profession than with higher education institutions. This model, which prevails in countries influenced by the Napoleonic model, led to a co-management of the system by the ministry and representatives of the profession (Musselin 2001/2004). Considering state-academics as well as state-universities relationships therefore leads to reframing the coordination triangle developed by B. Clark (1983) and to analyse the type of coordination in use to manage the academic profession as well and as much as the type of coordination which prevails to manage higher education institutions with.

To conclude with this state of the art, it should be noticed that few studies mix the two broad perspectives of analysis we described in this first section of the introduction. The correlation between, on the one hand, the type of policy network/regime (which exists in each country and characterize its higher education system) and, on the other hand, the type of public policies (in terms of content and impact) and state intervention prevailing in this country, is hardly discussed and analysed, with a few exceptions (Kogan, Bauer, Bleiklie and Henkel 2000, Musselin 2001/2004).

\section{Three possible redefinitions of the role of the nation state which affected higher education}

One further characteristic of the literature mentioned above is to look at higher education per se, to consider it as a singular sector, distinctive from other public sectors, despite it strongly relies on public funding. However comparing the reforms and transformation experienced by European higher education systems and those affecting the European public sectors, it is clear that what is described as the recent redefinitions of the state in the public sectors can be applied to higher education. We can thus develop the argument that European nation states are increasingly seeking to steer their higher education systems, along with other key public services, in directions which are consistent with national policies.

10 In a comparison between academic labour markets in France, Germany and the United States, C. Musselin (2005, chapter 7) argued that French universities first of all work as shelters for French academics, while German universities (at least until 2001 and the progressive introduction of merit salaries) behave as investors betting on their professors when they recruit them, and US universities are engaged in a employerwage earner relationship. 
There are three possible redefinitions of the role of the nation state evident since the $1980 \mathrm{~s}$, which may play out differently in different jurisdictions. In this second section, we will describe how concrete changes identified in many other public sectors are also observable in higher education.

\subsection{A stronger management of the public sector}

A first redefinition consists of the transformation of the public sector into a more restricted and managed sector. In the UK, where this redefinition had a large impact, it might be called the New Right or Thatcherite reform strategy. But, even if at a lesser extend, such a trend affected all European countries and led to reforming the public sector and to depart from the preceding period. Between the 1940's and 1980's, a number of European countries substantially increased the size of their public sector and welfare states (de Swann 1988), for example, expanding social security, health care and education programmes. The massification of higher education was one part of this wider trend, usually financed through public taxation and free to the student. At this point, the Mertonian concept of higher education autonomy in some countries and the interventionist conception in others, remained strong. From the late 1970 's onwards, however, political pressure to reduce the burden of taxation associated with the large Welfare state led to concerted efforts to reverse this long term pattern of public sector expansion and to ensure greater value for money, privatise nationalised industries, reduce trade union power and to increase productivity in the extended public sector. There was now a political desire to shrink the size and power of the public sector. Given the presence of well organised producer interest groups within the public sector (trade unions, professional associations), these changes were strongly resisted and led to a strong top down and confrontational management style. In almost all countries, large reforms of the public administration have been launched (see Bezes 2001 and 2005 for France for instance, Pollitt and Bouckaert 2004 or Page and Wright 2006 for a comparison of diverse European countries) in order to improve its performance and efficiency.

High profile student unrest, the post 1968 'long march through the institutions' of Marxist groupings and trade union strikes put Universities firmly on the radar screen. Efficiency, value for money and ensuring strong management were concerns for politicians and policy makers in the University sector as in the other public services. Universities were asked to increase their productivity, to develop new missions and in particular to achieve a leading role in technology transfer and innovation, to reduce their operating costs, to improve their dropout rates, to match the demands of the job market, to pay attention to the societal needs (Dill and Sporn 1995), etc. Increasing the autonomy of more strongly governed universities has repeatedly been affirmed as the best option to reach such objectives. Reforms (such as those led in the Netherlands, de Boer, Denters and Goedegebuure 1998; de Boer and Goedegebuure 2001) therefore aimed at reinforcing the executive leadership of universities and reducing the power of deliberative bodies and collegial governance (Braun and Merrien 1999, Braun 2002, Stölting and Schimank 2002) while universities were equipped with managerial instruments (strategic plans, audits, etc.), tools (management software for instance), indicators (Cave, Hanney and Kogan 1991) and practices.

As can be seen, the effects of these 'reforms' led to significant changes in the balance of power within the higher education sector. Senior management and non executives' power bases were strengthened. On the other hand, public sector trade unions and rank and file faculty lost power. The state intervened more actively in the higher education system and in a 
more self confident manner. Supporters of such reforms would also argue that the use of market like mechanisms increased consumer 'voice' and challenged public sector producer capture of the institutions.

In parallel, the role of the state in the provision of higher education has been redefined in various ways. In some countries, like Portugal, the development of the private sector has been encouraged in order to cover the lack in higher education and many private institutions have been created. In others, reductions in public funding occurred (in 1981 for instance, deep and very visible cuts were made in the budgets of some UK universities as a national policy decision to shock the system into radical change), leading to reducing the number of academic positions despite the increase in student numbers (in Germany for instance, according to Enders (2000), the number of students rose from 232\% between 1975 and 1995 while the number of academic positions rose from 130\%). This led universities to search for other forms of funding, while some countries (the United Kingdom again, but also Germany and Austria for instance) stimulated the participation of families by increasing or introducing fees. In almost all countries finally, the balance between the ministry and higher education institutions has been modified in favour of the latter.

This redefinition of the role of the state in providing and funding higher education has been accompanied by attempts at transforming the modes of action of the ministers. As highlighted by I. Bleiklie (2000), the traditional tools did not disappear: governing by rules remains current in higher education and many countries (Italy and Norway among others) for instance decreed the introduction of the Bachelor-Master scheme in their universities. But many new instruments of governance also flourished. Some of them aim at delegating decision-making to new kind of bodies: this lead to the creation of intermediary bodies such as agencies of all kind. Others, like contracts for instance, aim at introducing ad-hoc negotiations. Still others consist in abandoning ex-ante control in favour of ex-post evaluation: this provoked the irresistible expansion of assessment/evaluation bodies all over Europe (Campbell 2003, see Schwarz and Westerheijden 2004 for a complete panorama of this trend on 20 European countries).

This movement is sometimes described as a disengagement of the state. But it rather reflects a new form of state engagement in higher education. Universities are being increasingly identified as "key actors" (as knowledge diffusers, research producers and innovation inducers) in "knowledge societies", European governments have never been as attentive to higher education and research than today. Universities are on the policy agenda in every country and governments search for means enabling a less expensive and more efficient management of the sector.

\subsection{The 'hollowing out' of the nation state}

A second redefinition consists of the 'hollowing out' of the nation state (Rhodes, 1997; Pierre, 2000; Frederickson, 2005). Even if most of the literature on this evolution is more recent than the literature on the stronger management of the public sector, evidence can be found in the past and developed in parallel with stronger management. In this account, the nation state is losing functions, legitimacy and authority to an increasing range of alternative actors and national borders are blurring. In particular, functions move from the nation state upwards to the EU level (including the Lisbon process) or downwards to 'strong regions'. In many countries, the regions received more prerogatives through decentralisation acts. In France for 
instance, two laws, the first in 1982 and the second in 2003 reinforced the scope of action of the régions, the départements and the cities in many domains (social services, vocational training...). As a result the number of public actors directly involved within the management of a public sector increased. Furthermore, routine service delivery functions are contracted out to a range of non state providers. Political parties are in decline; but social movement organisations (such as Greenpeace and Oxfam) grow. Legitimacy deficits lead state actors to consult with non state actors and to form coalitions to secure political support. Command led control systems give way to network based forms of management.

While in many European countries, the Post Second World War period has been characterized by quasi monopolistic relationships between the national authorities and their higher education systems, profound changes occurred in the eighties and upwards. Higher education is one important function which may be devolved from the national to the augmented regional level, but which also operates at a EU level. The role of regional/local public authorities in higher education increased ${ }^{11}$. This move has been allowed either by the devolution of prerogatives on higher education to specific territories (United Kingdom, Spain), by an increase in autonomy on these issues to already decentralised units (Germany ${ }^{12}$ ) or by the voluntary action of some local actors to be recognised a say ${ }^{13}$ (France).

The implication of supra-national actors in higher education is somewhat more complicated as the European Commission formally has no competence on this issue. Nevertheless, as clearly and precisely shown by A. Corbett (2005), it does not mean that there exists no European policy on higher education (cf. for instance the Erasmus programmes, the creation of the ECTS...). Furthermore the European Commission has competence over research and has developed for more than 20 years Framework Programmes, which impact on European universities through the funding of collaborative research projects. Last, but not least, intergovernmental initiatives such as the Bologna process, even if not led by the $\mathrm{EU}^{14}$, affected the national systems of the signing countries (Alesi, Bürger, Kehm and Teichler 2005, Krücken et al. 2005, Witte 2006, Musselin forthcoming) and can not be ignored by the national education ministries. To these rather direct influences, one could finally add the more indirect role of actors such as the OECD in the development of international benchmark and good practices.

Consequently, higher education institutions operate in regional, national and international networks simultaneously and have to engage with a wide range of different stakeholder groups. The distribution of power is more diffuse and pluralist than in the reforms in public management. Indeed the proliferation of different networks may become bewildering, leading to a sense that there is no one actor who can be held effectively accountable. There is no crude

11 In many countries this recreated the situation prevailing before the Second World War when the development of universities was deeply intertwined with the trajectory of the local territory where they were located.

12 See for instance Kehm and Lanzendorf (2006).

13 In France the laws of decentralisation did not concern higher education which remains a national issue. But since the mid-eighties, local actors (regions, departments or cities) claim to be involved in decisions pertaining to higher education and affect part of their budgets to fund equipments, buildings, fellowships, research projects and even some positions. If higher education is still not decentralised, some procedures, such as "Universités 2000" or the contracts regularly signed between each region and the state have offered windows of intervention to local public actors, and to regions in particular.

14 But the EU, and more precisely the Commission, is part of the process and C. Racké for instance argues that this process, although intergovernmental, facilitates the (indirect) intervention of the Commission on higher education and legitimates the production of "commission papers" on this topic (Racké 2006). 
concentration of power in the hands of the upper echelons or disempowering of public sector trade unions or academic faculty who remain important stakeholders. The state 'holds the ring' rather than intervene directly within the sector. Further analysis is needed to discover whether some higher education network actors are nevertheless more powerful than others: this may be linked to control over finance or the possession of a central or nodal position within the network (networking skills themselves become an important form of social capital). Networks may also be dominated by closed social elites rather than being open to democratic forces.

\subsection{The democratic revitalisation}

A third redefinition of the state concerns attempts to ensure the democratic revitalisation of pathological and over bureaucratised traditional forms of public administration. In many South American countries, for example, writers on the post military governments which have emerged over the last twenty years stress the importance of the democratic basis of the state where the individual is seen as a citizen and not an object (see Bresser-Pereira 2004 on developments in public management in Brazil). DeLeon (2005) sees the development of more participative forms of public management as a strategy for responding to falling levels of trust in government. This argument is close to Manin (1996) who explains the rise of the deliberative democracy through an experience of the limits of the representative democracy.

Consequently, the monopoly on expertise previously recognized to public servants has been discussed and critiqued as well as their capacity to define public interest. This led to a stress on more participation from various stakeholders in the construction of public decisions. Profane knowledge was recognized as a form of expertise in its own right while new devices were created to multiply the opportunity of participation and deliberation in the direction of larger circles (i.e. not only to politicians, public servants and academic experts). Such trends are observable in comparable public services arenas such as health care where recent public policies have been developed to construct an informed public opinion which can act as a countervailing force to the views of clinicians and scientists. For example, technology assessment arenas in such areas as evidence based health care (e.g. the sophisticated public consultation processes developed by the UK National Institute of Clinical Excellence to supplement the scientific base in relation to explicit health care rationing decisions), consensus conferences (Joss and Durant 1995), hybrid forums (Callon, Lascoumes and Barthes, 2001), and deliberative bodies at the national level (for instance the "Commission nationale du débat public » in France) have all expanded.

Within the University context, this democratising redefinition would suggest strong staff and student and stakeholder participation in the governance of the institution. This took different forms. Some countries (Germany, Netherlands, Norway...) passed new laws and created university boards (Mayntz 2002), consisting partly or exclusively of non-university members, expected to play the role of the American board of trustees and to set priorities, approve the budget, valid strategies etc. Others, like the United Kingdom introduced non-academic members in their national research councils.

Democratising would also lead to a stress on the social function of the University as a key part of local civil society and strong interactions with local stakeholders. Teaching may be delivered through non traditional modes and research is likely to include a strong applied and 'useful' emphasis. Some authors (Gibbons et al. 1994, Novotny et al. 2001) announced a 
transition of knowledge production processes from Mode 1 to Mode 2, i.e. (among other things) a drift from research agendas defined by academics according to their discipline to research agendas defined in order to solve multidisciplinary societal needs and problems.

In terms of the distribution of power, the democratic revitalisation redefinition can be seen as distinct both from the stronger management of the public sector and the "hollowing out" of the state. There is here a strong scepticism about according too much power to senior leaders and a demand for traditional forms of democratic accountability (including elections of Rectors). The base becomes more important vis-à-vis the apex. Universities also become more connected to influence from their local publics and less endogenous. So power may shift to those with political skills and bases, and those able to engage in acts of collective organisation.

\section{Two main narratives of public sector reforming and how they apply to HE}

In the previous section, three principal redefinitions of the role of the state were described, which can be observed in the public sector of all European countries and which all affected higher education systems as well. Each nevertheless occurred with more or less intensity from one part of Europe to the other. They also differently combined. While the hollowing out of the state often happened along with some concerns for democratic revitalisation, countries more focused on reinforcing the management of their public sector were less affected by the two other types of redefinition. Finally the same transformation may have taken different forms. For instance, the transformation of the public sector has been strongly associated with managerialism in some countries and with modernization in others.

Our ambition in this third section is no more to point at the changes but to identify the rationales which were mobilised to push for these changes and the rhetoric helping to make sense of these changes. In order to make sense of these diverging implementations and qualify the transformations experienced by different countries and their higher education systems, it is suggested to link them to two main narratives of public services reform: the New Public Management and the Network governance. They are called narratives because they are not pure analytical fand theoretical rameworks aiming at comprehension (in the Weberian sense): they both mix technical and also political and normative elements. They each tell a policy and management story, which has been more or less influential in each country as well as they can be linked to specific conceptions and theories regarding the relationships between the state and society. Each time, we will describe what the narrative consists in and the way it can apply to higher education will be developed.

\subsection{The New Public Management}

The NPM is a well known public sector reform wave emerging in the UK under the Thatcher governments of the 1980s but which has also been influential internationally in such jurisdictions as Sweden and New Zealand (Hood, 1991; Hood, 1995; Ferlie et al, 1996). The UK has exported some NPM reform instruments globally (privatisation; devolved executive agencies) so the NPM was more than a narrow UK trend. The NPM relies on (1) markets (or quasi markets) rather than planning, (2) strong performance measurement, monitoring and management systems, with a growth of audit systems rather than tacit or self regulation and 
(3) empowered and entrepreneurial management rather than collegial public sector professionals and administrators (Andresani and Ferlie, 2006). The NPM seeks to produce a smaller, more efficient and more results orientated public sector. It is influenced by ideas in organisational economics such as principal agent theory which stress incentives and performance. There is a concentration on goals of efficiency, value for money and performance rather than democracy or legitimacy. There is a suspicion of monopoly public sector producers (including public sector professionals) and a desire to shift power to consumers and managers. There is a desire to increase the strength of hierarchy, either directly through line management or indirectly through strong contracts within a principal/agent framework. Here the centre sets the strategic framework and governance instruments ('steering not rowing'); and the periphery is given operational freedom to deliver but only within this strategic framework. NPM ideas are often 'owned' by the Ministry of Finance or the Prime Minister's/President's office rather than the spending departments such as the Ministry of Education and are imposed on public services at the field level in a top down fashion.

There may be some tension between these three underlying principles and different NPM subtypes have emerged (Ferlie et al, 1996). For example, NPM may be associated with principles of 'liberation management' and the enhancement and empowerment of managerial action - as in the Gore Reinventing Government reforms in the USA of the 1990s - or alternatively with the proliferation of ex post audit systems (Power, 1997) which led to defensive and risk averse management (as in the UK case). Contrary to the institutionalist view that public sector reforms have only superficial impact, Ferlie et al found that at least in the sector of UK health care, the impact on NPM reforms on intermediate indicators of organisational process had been considerable.

There is currently a debate about the international breadth of the NPM (is it a Anglo Saxon construct to which many other jurisdictions are averse or has it diffused more widely?) and its longevity (whether or not we have moved into a post NPM era of network governance). A recent overview (Ferlie et al, 2005) found substantial evidence of NPM breadth and depth and concluded that it would as yet be premature to conclude that the era of NPM was over. Even late comers as France finally adopted NPM reforms, without using this labelling nevertheless: the recent introduction of new public budget procedures (the LOLF, loi organique sur la loi de finances) follows the main principles described above.

In terms of the application of NPM ideas to the higher education sector, we would predict the following 'signs and symptoms'. These "indicators" are not only examples of what may happen. They will then be used in the comparative conclusion of the book to determine the importance of the penetration of NMP in each studied country.

a) Market based reforms:

a1 Stimulation of competition for students between HEIs, such as development of real 'prices' for teaching fees as a basis on which trading in this market can take place, introduction of higher student fees to empower students as consumers and drive up teaching quality levels, use of voucher for students or other form of students' support can be seen as a quasi-market based reforms;

a2 Market based research funding (for private and public higher education and research institutions);

a3 Policy stress on diversity and choice rather than integration and planning;

a4 Encouragement of private sector providers to enter the market; 
a5 Market exit of failed public providers is acceptable;

b) a hardening of soft budgetary constraints:

b1 Stress on financial control in state/governmental policy;

b2 Efficiency and value for money;

b3 "Commodification" of activities in policies (for instance the introduction of intellectual property rights), and in explicit narrative;

c) Stress on performance: elaboration of explicit measurement, assessment and monitoring of performance in both research and teaching; development of audit and checking systems (auditisation variant of NPM);

d) Concentration of funds in the highest performing higher education institutions (incentivisation of the supply side);

e) The Ministry and its agencies attempt to steer the system vertically, through setting explicit targets and performance contracts;

f) Higher education institution governance:

f1 In the realm of governance, the development of 'strong rectorates' and non executive members drawn from business;

f2 Move to appointed rather than elected senior posts;

f3 Reduction in the representation of faculty and trade unions in higher education institution governance;

g) Managerial roles:

g1 Stronger overt managerial roles of rectors, deans, head of departments;

g2 Development of 'management must manage' doctrines and practices, i.e. who has responsibility for management must have the means and the will to manage (liberation management NPM subtype);

h) Growth of performance related pay for faculty and private sector style Human Resource Management

The UK remains a key index case for NPM and an exporter of NPM reforms. Within the UK, specific public services varied in the timing of the importation of key NPM ideas and in the capacity of the centre to impose them on the field. Health care can be seen as an early mover: it was politically sensitive and visible; and the Department of Health had national level control over the system. Higher education can be seen as a medium mover, following somewhat behind Health (e.g. Griffiths, 1983, on NHS general management; Jarrett, 1985, on strengthening the executive role of the Vice Chancellor) and with a lower capacity of the centre to impose change. Nevertheless, the capacity of the planning council to incentivise and persuade individual higher education institutions is considerable and should not be underestimated. Criminal justice was a later mover still, but came on stream in the 1990s.

Nevertheless the influence of NPM goes far beyond the UK. Some of the "signs and symptoms" described above are observable in other countries and some (as the "a" in almost all). Just to take a few examples, the higher education system in the Netherlands has been strongly influenced by the NPM narratives and meets at least 6 of them (b, c, e, f, g and h) and some partially. In a country like Germany, where the NPM narrative had less success, 4 signs (b, d, e and h) are present nowadays, while many of the measures of the recent Norwegian "Quality reform" meet the NPM symptoms.

\subsection{Network Governance Narrative}


As stressed in the second section of this introduction, political scientists in the 1990s pointed to the "hollowing out' of the traditional nation state as functions moved upwards or downwards (Rhodes, 1997) away from the national ministerial level, or had to be negotiated with many social actors within the implementation phase (thus often relying on more deliberative democracy). Understanding and indeed reconceptualising 'implementation deficits' through the development of more bottom up and emergent models of implementation was an early contribution of this literature.

But this raises a governance problem (Klijn, 2005). Given an outsourcing of direct responsibility for production through privatisation, outsourcing and agentification, the state now had to steer through contract, alliance building and partnership and persuasion rather than hierarchy. Contracts could be weak or difficult to enforce in practice. The concept of multi level 'governance' emerged to make sense of these new conditions. 'Governance' was a deliberately looser term than the old concept of 'government' (Le Galès 1995, Borraz and Le Galès 2001, Kooiman, 2003). It not only refers to network based forms of organising but also to allow more balance among the involved actors, more deliberative democracy and, consequently, the co-production of public policies among more numerous, more diverse and more equal actors.

In countries which early adopted a NMP rhetoric, some writers understood the development of the literature on this narrative as a sign of the emergent post NPM organisational form (Newman, 2001). In the UK for instance, this was associated with the Third Way ideas of the early Blair governments and policy level reflection in the late 1990s on the weaknesses and also the strengths of NPM based reforming which should be retained (such as its stress on performance improvement). The network governance model therefore builds on criticisms of the NPM in the recent years. Building linkages across public policy actors in order to deliver complex change is a key theme (Klijn, 2005). There were excessive transaction costs associated with escalating and often substantively pointless NPM driven audit sytems (Power, 1997) which also led to a dangerous disengagement of public sector professionals (doctors; teachers; academics) from the official change agenda.

But such analysis should not be misleading. First, this narrative is most of the time is developed in opposition or as distinct from the NPM narrative. Moreover the factors associated to the network governance narrative developed well before authors begun qualifying them and labelling them as "network governance", in sectors with complex or 'wicked' policy issues which cross traditional boundaries and demand lateral working (e.g. anti drugs policy). Increased policy complexity may be characteristic of later modern governmental systems (eg climate change; food safety). Furthermore, in many countries the network governance narrative developed independently from the reflection on NPM and well before any introduction of some NPM.

Within the network governance narrative, a greater range of actors and interactions emerges, and the central state plays more of an influencing and less of a directing role. It governs with society and not above it (Padron, 2006). There is a shift from vertical to lateral forms of management. There is devolution of power downwards from the centre of the nation state to lower tiers and also upwards to higher including European tiers. In such systems, coordinating power is shared between social actors, possibly operating at multiple levels of analysis. Knowledge and 'best practice' spreads across the network, based in high trust, repeated interactions and a 'clannish' culture. There is dense interaction and inter dependency between network partners. The network develops self organising and self steering capacity. The role of 
the state is distinctive only as a relationship facilitator : it brings actors together, builds trust, arbitrates and verifies interactions (Padron, 2006 ; Klijn, 2005). 'Joined up' policy needs to bring together various executive agencies and other non governmental actors as co producers of a complex good. Accountability relationships are a way of 'giving account' to local publics and not an ex post state driven system of checking. This narrative builds on the pioneering work of a number of French and Dutch public policy scholars on network based forms of public management (Le Gales 1995; Kickert et al, 1997; Klijn, 2005).

Instead of the NPM policy mix of hierarchies plus markets, the public management network becomes within this narrative the prime instrument of coordination. It includes novel concepts of networks, collaboration, diversity, inclusion and devolution. There are some strong similarities with the science policy literature on so called Mode 2 knowledge production (Gibbons et al, 1994, Novotny et al. 2001) which stresses co production of knowledge between the higher education institution and an extended range of non traditional actors. However, some networks form integrated and cohesive 'policy communities' which are captured by a narrow range of powerful interest groups (Rhodes, 1998).

No country appears to be an index case for the network governance narrative but most countries display evidence for the development of larger networks and for the introduction of new actors in many sectors.

In terms of policy and management implications for the higher education sector, the networkgovernance narrative implies the following "signs and symptoms", which will also be used at the end of the book to assess the level of penetration of the network governance narrative in each country:

a) Development of networks between higher education institutions and between higher education institutions and other social actors;

b) These networks are develop substantial self steering and self organising capacity;

c) Some networks are designed with the explicit goals of joint problem recognition, joint problem solving, organisational learning and dissemination of 'good practices'/leading-edge knowledge;

d) External control systems take the form of 'light touch' systems and of professional self-regulation;

e) Networks play a significant role in governance of the higher education system; in these network organisations, governmental and non-governmental organisations of different levels and/or of different functional areas take part;

f) The Ministry of Education and its higher education agencies adopt indirect and shaping role: they 'hold the ring' between many different actors as the ultimate guardians of the public interest; there is a more 'hands off' style of system management at national level, with little emphasis on national level target setting and planning (facilitative state);

g) In terms of senior management style, there is an emphasis on softer leadership skills, visioning and networking based approaches; there is an emphasis on distributed leadership and team based approaches rather than the highly individualised management typical of NPM;

h) Human resources management systems reward high performing teams rather than individuals; there is only limited salary differentiation in order to preserve collective purpose within the network; 
As mentioned above, no country can be described as an index case, but some signs can be found in different cases. In France, for instance, three symptoms are present (a, b, and c) and two are partially observable (e and f). In particular, the recent possibility for French higher education institutions to join into a common super-structure called PRES (pole of research and higher education) is very typical for sign "e". In Germany the emergence of various accreditation agencies provides a good example for the development of an increasing indirect role of the state ("f"). And sign ("e") is relevant to most European countries with the development of higher education and research policies at the European level and the strengthening of infra-national levels (regions, Länder etc.) in many cases.

\section{How this book is organized?}

The rationale of this book is to mobilise these two narratives in order to analyse the transformations experienced by higher education and research systems in seven European countries, France, Germany, Italy, the Netherlands, Norway, Switzerland and the United Kingdom.

Rather than choosing one of the two narratives as one analytical framework, we decided to describe the main changes which occurred in each country and to question what can be explained with the NPM narrative and what can be explained with the network governance narrative. The main underlying idea is that although they are some contradictions and incompatibilities between the two narratives, they are not exclusive and can both develop in the same country. Even more: we expect to observe that both narratives are more or less present in each country and differently combine one with another.

The structure of the book will thus be the following. The changes experienced in each of the seven countries will be depicted and analysed in seven national chapters. On purpose, the internal structure of the chapters is not harmonized. It should rather reflect the specificity of each case and its main characteristics rather than try to respect common issues. Nevertheless, all chapters share two objectives. The first is to identify the respective influence and impact of the two narratives on the steering of universities. The second is study the consequences of this transformations on two "tracers" i.e. two more empirical issues. Both tracers have been chosen because they are present in all of the seven countries and can be affected by the two narratives.

The first tracer concerns research funding. One the one hand, new mechanisms of allocation have been developed, leading to more accountability and follow up, i.e. to more managerial behaviours. On the other, researchers are encouraged to diversify their sources and to build networks of funding.

The second tracer deals with the development of doctoral schools. Universities have been encouraged to formalise and structure doctoral studies. It can be understood as (and justify by) a need to structure and have more control over rather informal forms of training. The objective of producing PhDs in less than three years, or of improving the professional insertion of new doctorates reveals a trend towards a standardization of this period of apprenticeship. But these reforms are also threatening the personal master to disciple relationship with characterized doctoral training before and lead to more collective, network oriented forms of organizing. 
The aim with these two tracers is too leave the macro national level privileged by the analysis of the reforms in each country and identify some of their impact at the level of the research units and of the researchers located in universities. Each of these tracers would need a much longer development if one wanted to describe and analyse in depth how they changed overtime in the seven countries. Each chapter will only deliver a brief overview of the impact of the national reforms on them. Further publications and the different $\mathrm{PhDs}$ prepared by doctoral students ${ }^{15}$ in the seven countries will provide more detailed and extensive analysis.

The seven national chapters will be followed by a conclusive chapter which first aims at comparing the seven countries by looking at how closely they meet the scenarios developed above for each of the two narratives when applied to higher education. This conclusion also has more reflexive ambitions. It draws upon the empirical results and the comparison across countries to discuss how the two prevalent narratives used by the public management perspective display stimulating analytical possibilities when combined, rather than opposed. It also reflect on how the hybrid forms produced by their varying implementation in the seven countries can provide further theoretical insights for the understanding and analysis of higher education systems as well as public services to a larger extend, in Europe.

\section{References}

Alesi, B., Bürger S., Kehm B. and Teichler U. (2005): Bachelor and Master Courses in Selected Countries Compared with Germany, Bonn and Berlin, BMBF.

Amaral A., Meek V. Lynn, Larsen I.M. (eds.) (2003): The Higher Education Managerial Revolution?, Dordrecht, Boston, London, Kluwer Academic Publishers,.

Andresani, G. and Ferlie, E. (2006) 'Studying Governance within the British Public Sector and Without: Theoretical and Methodological Issues', Public Management Review, 8(3): 415432 .

Bezes P. (2001): "Defensive versus Offensive Approaches to Administration Reform in France (1988-1997): the Leadership Dilemmas of French Prime Ministers", Governance, 14(1), pp. 99-132.

Bezes P. (2005): 'Le modèle de 'l'Etat - stratège' : genèse d'une forme organisationnelle dans l'administration française", Sociologie du travail, 47 (4) pp. 431-450.

Bleiklie I. (2000): "Policy Regimes and Policy Making”, in Kogan, M., Bauer, M., Bleiklie, I. and Henkel, M.: Transforming Higher Education: A comparative study, London and Philadelphia, Jessica Kingsley Publishers, pp. 53-87.

Bleiklie, I., Høstaker, R. and Vabø, A. (2000) : International Study of Higher Education : Norway, London and Philadelphia, Jessica Kingsley Publishers.

15 Four doctoral students are working on the transformation of research funding right now : J. Barrier for France, F. Camerati for the United Kingdom, Gigliula ????? for Norway and ???? for Italy. Three are working on doctoral schools : L. Bashung for Norway and Switzerland, A. Dahan for France, Laura ??? for Italy and the United Kingdom. 
Bloor D. (1976): Knowledge and Social Imagery, London, Routledge and Kegan Paul, 1976.

Boer (de) H., Denters B. and Goedegebuure L. (1998): "Dutch Disease or Dutch Model? An Evaluation of the Pre-1998 System of Democratic University Government in the Netherlands", Policy Studies review, 15, pp. 37-50.

De Boer, H., Enders, J. and Schimank, U. (2007) 'On the Way towards New Public Management? The Governance of University Systems in England, the Netherlands, Austria and Germany', In Jansen, D. (ed.) New Forms of Governance in Research Organizations Disciplinary Approaches, Interfaces and Integration, Dordrecht, Springer.

de Boer H. and Goedegebuure L. (2001): "On limitations and consequences of change: Dutch university governance in transition", Tertiary Education and Management, 7, (2), pp. 163180.

Borraz O. and Le Galès P. (2001) : "Gouvernement et gouvernance des villes", in Leresche J.P. (ed.) : Gouvernance locale, coopération et légitimité : le cas suisse dans uen perspective comparée, Paris, Pedone.

Braun D. (2002): "Regulierungsmodelle und Machstrukturen an Universitäten", in Stölting E. and Schimank U. (eds): Die Krise der Universitäten, Opladen, Westdeutscher Verlag.

Braun, D. et Merrien, F.-X. (eds) (1999) : Towards a Model of Governance for Universities? A Comparative View, Higher Education Series, Londres, Jessica Kingsley Publishers.

Bresser-Pereira, L.C (2004) 'Democracy and Public Management Reform: Building The Republican State', Oxford: Oxford University Press

Callon M., Lascoumes P., Barthe Y. (2001): Agir dans un monde incertain : essai sur la démocratie technique, Paris, le Seuil.*

Campbell, D.F.J. (2003): "The Evaluation of University Research in the United Kingdom and the Netherlands, Germany and Austria", in Shapira P. and Kuhlmann S. (eds.): Learning from Science and Technology Policy Evaluation, Cheltenham (UK) and Northampton 5USA), Edward Elgar Publishing, pp. 98-131.

Cave M., Hanney S. and Kogan M. (1991): TheUse of Performance Indicators in Higher Education. A critical Analysis of Developing Practices, London, Kingsley Publishers.

Cerych L. and Sabatier P. (1986): Great Expectations and Mixed Performance: Implementation of European Higher Education Reforms, Stoke-on-Trent, Trentham Books.

Clark B.R. (1983): The Higher Education System: Academic Organization in Cross-national Perspectives, Berkeley, University of California Press.

Corbett A. (2005) : Universities and the Europe of Knowledge. Ideas, Institutions and Policy: Entrepreneurship in European Union Higher Education Policy, 1955-2005, London, Palgrave Macmillan. 
DeLeon, L. (2005) 'Public Management, Democracy and Politics', in Ferlie, E., Lynn, L. and Pollitt, C. 'The Oxford Handbook of Public Management' Oxford: Oxford University Press

Dill D. (1996): "Higher Education Markets and Public Policy", Higher Education Policy, 10 (3-4), pp. 167-185.

Dill D. and Sporn B. (1995): Emerging Patterns of Social Demand and University Reform: Through a Class darkly, Oxford, Pergamon Press.

Enders J. (1996): Die Wissenschaftlicher Mitarbeiter. Ausbildung, Beschäftigung und Karriere der Nachwuchswissenschaftler und Mittelbauangehörigen an den Universitäten, Frankfurt am Main, Campus Verlag.

Enders J. (2000) «A Chair System in Transition: Appointments, Promotions, and Gatekeeping in German Higher Education », in Philip AltBACH (ed.), The Changing Academic Workplace. Comparative Perspectives, Boston, Boston College Center for International Higher Education, 2000b, p. 25-50.

Enders J., (ed.) (2001) Academic Staff in Europe: Changing Contexts and Conditions, Westport, Conn. And London: Greenwood Press.

Ferlie, E., Musselin, C. and Andresani, G. (2007) 'The 'Steering' of Higher Education Systems: A Public Management Perspective', Higher Education Looking Forward. Relationships between higher education and society, ESF, pp. 59-78.

Ferlie, E., Musselin, C. and Andresani, G. (forthcoming 2008) 'The 'Steering' of Higher Education Systems: A Public Management Perspective', Higher Education.

Frederickson, M.G. (2005) 'Whatever Happened to Public Administration? Governance, Governance Everywhere', in (eds) Ferlie, E., Lynn, L. and Pollitt, C. 'The Oxford Handbook of Public Management' Oxford: Oxford University Press.

Gibbons, M. et al (1994) 'The New Production of Knowledge’ London: Sage

Goedegebuure L., Kaiser F., Maassen P., Meek L. and de Weert E. (Eds) (1993): Hochschulpolitik im internationalen Vergleich, Güterloh, Verlag Bertelsmann Stiftung

Griffiths Report (1983) 'NHS Management Enquiry’ London: Department of Health

Guetzkow J., Lamont M., Fournier M., Mallard G., and Bernier R. (2002): "Evaluating Creative Minds: The Assessment of Originality in Peer Review", Contribution for the symposium "Creativity," International Association of Sociology, Brisbane, 2002.

Hood, C. (1991) 'A Public Management for all Seasons?', Public Administration, 69 (Spring), 3-19

Hood, C. (1995) 'The New Public Management in the 1980s: Variations on a Theme', Accounting, Organisation and Society, 29(2/3), 93-110 
Hood, C., James, B., Peters, G. and Scott, C. (2004) 'Controlling Modern Government', Cheltenham: Edward Elgar

Joss S. and Durant J. (eds.) (1995): Public Participation in Science: The Role of Consensus Conferences in Europe, Science Museum.

Jarrett Report (1985) 'Report of the Steering Committee for Efficiency Studies in Universities', London: Committee for Vice Chancellors and Principals.

Kehm B. and Lanzendorf U. (2006): Germany: 16 Länder Approaches to Reform, in Kehm B. and Lanzendorf (eds.): Reforming University Governance - Changing conditions for research in four European Countries, Bonn, Lemmens.

Klijn, E-H (2005) 'Networks and Interorganisational Coordination', in (eds) Ferlie, E., Lynn, L. and Pollitt, C. 'The Oxford Handbook of Public Management' Oxford: Oxford University Press

Kickert, W.. Klijn, E-H., and Koppenjan, J.F.M (eds) (1997) 'Managing Complex Networks' London: Sage

Kogan, M., Bauer, M., Bleiklie, I. and Henkel, M. (2000): Transforming Higher Education : A comparative study, London and Philadelphia, Jessica Kingsley Publishers

Kogan M., Hanney S. (2000): Reforming Higher Education, Londres and Philadelphie, Jessica Kingsley Publishers.

Kooiman, J. (2003) 'Governing as Governance’ London: Sage

Krücken G. (with J. Bunzmann, L. Hürter, M. Kandzorra, K. Kloke, J. Körnert, S. Ludwig, B. Podolšak and Y. Prill) (2005): Hochschulen im Wettbewerb. Eine Untersuchung am Beispiel der Einführung von Bachelor- und Masterstudiengängen an deutschen Universitäten, Report, Bielefeld, Department of Sociology, University of Bielefeld.

Latour B. (1987): Science in action: How to follow scientists and engineers through society, Cambridge, Harvard University Press.

Le Galès P. (1995) : "Du gouvernement local à la gouvernance urbaine”, Revue Française de Science Politique, 45 (1), pp. 57-91.

Lehmbruch G. (1995): “Organisation de la société, stratégies administratives et réseaux d'action publique : éléments d'une théorie du développement des systèmes d'intérêts", in Le Galès P. and Thatcher M.: Les réseaux de politique publique; débat autour des policy networks, Paris, L'Harmattan.

Lynch M. (1993): Scientific Practice and Ordinary Action: Ethnomethodology and Social Study of Science, Cambridge, Cambridge University Press.

Maassen P. and Stensaker B. (2005): "The black box revisited: the relevance of theory-driven research in the field of higher education studies", in Henkel M. and Bleiklie I. (eds): 
Governing Knowledge; a study of continuity and change in higher education a Festschrift in Honour of Maurice Kogan, Dordrecht, Springer, pp. 213-226.

Mallard G. (2006): "Quand l'expertise se heurte au pouvoir souverain: la nation américaine face à la prolifération nucléaire, 1945-1953”, Sociologie du travail, 48 (3), pp. 367-389

Mallard G., Lamont M. and Guetzkow J. (2002): "The Pragmatics of Evaluation: Beyond Disciplinary Wars in the Assessment of Fellowship Proposals in the Social Sciences and the Humanities", Contribution for the conference Sociological Theory and Empirical Research, American Sociological Association Meetings, Chicago, 2002.

Manin B. (1996): Principes du gouvernement représentatif, Paris, Flammarion.

Marsh D. and Rhodes R.A. (eds.) (1992) : Policy Networks in British Government, Oxford, Clarendon Press.

Mayntz R. (2002): "University Councils: institutional innovation in German universities", European Journal of Education, 37 (1), pp. 21-29.

Mintzberg, H. (1979) 'The Structuring of Organisations', Englewood Cliffs, NJ: Prentice Hall.

Musselin C. (2001): La longue marche des universités françaises, Paris, Presses Universitaires de France, English translation C. (2004): The long March of French Universities, New York, Routledge.

Musselin C. (2005): Le marché des universitaires. France Allemagne, Etats-Unis, Paris, Presses de Sciences Po.

Musselin C. (forthcoming): "The Side-effects of the Bologna Process on national institutional settings", in Amaral A., Maassen P. , Musselin C. and Neave G. (eds.): European Integration and the Governance of Higher Education and Research. The challenges and complexities of an emerging multi-level governance system, Springer.

Neave (1986) : "On Shifting Sands: Changing Priorities and Perspectives in European Higher Education from 1984 to 1986”, European Journal of Education, 21 (1), pp. 7-24.

Neave G. and van Vught F. (1991): Promotheus Bound : the Changing Relationship between Government and Higher Education in Western Europe, Oxford, New-York, Pergamon Press.

Neave, G. et van Vught, F. (eds) (1994) : Government and Higher Education relationships across three continents : the Winds of Change, Oxford, New-York, Pergamon Press.

Novotny H., Scott P. and Gibbons M. (2001): Rethinking Science: Knowledge and the Public in an Age of Uncertainty, Cambridge, Polity Press.

Padron, L. (2006) 'Is NPM the Management Paradigm of UK HE: Or Better, Is It Still?', Working Paper, SUN PRIME collaboration, London: Royal Holloway, Centre for Public Services Organisations. 
Page E. C. and Wright V. (2006): From the Active to the Enabling State. The Changing Role of Top Officials in European Nations, London, Palgrave Macmillan.

Paradeise, C. (1998) : «Pilotage institutionnel et argumentation : le cas du département SHS au CNRS », in Borzeix, A., Bouvier, A. andt Pharo, P. (eds.) : Sociologie et connaissance Nouvelles approches cognitives, Paris, CNRS Editions.

Pierre, J. (ed) 'Debating Governance’, Oxford: Oxford University Press

Polanyi M. (1962): "The Republic of Science, its Political and Economic Theory ", Minerva, 1 (1), pp. 54-73.

Pollitt, C. and Bourckeart, G. (2004) 'Public Management Reform: A Comparative Analysis' Oxford: Oxford University Press

Power, M. (1997) ‘The Audit Society’ Oxford: Oxford University Press

Racké C. (2006): "The Bologna process and the E.U: neither Within nor Without", workshop on Analysing the implementation of the Bologna Analysing change in higher education policies : the Bologna process under scrutiny, AFSP - CSO - CIERA, Paris.

Radaelli C.M. (2000) : "Logiques de pouvoir et récits dans les politiques publiques de l'Union européenne“, Revue française de science politique, 50 (2), pp. 255-275.

Reed, M. (2002) 'New Managerialism, Professional Power and Organisational Governance in UK Universities: A Review and Assessment', in 'Governing Higher Education: National Perspectives on Institutional Governance', (eds) Amaral, A., Jones, G.A and Karseth, B., Dordrecht, Netherlands: Kluwer, pp163-185

Rhodes, R.A.W (1997) 'Understanding Governance’, Buckingham: Oxford University Press

Rhodes, R.A.W (1998) 'Beyond Westminster and Whitehall', London: Unwin Hyman

Rouban, L. (1988) : L'Etat et la science, Paris, Editions du CNRS.Stone D. (1997): Policy Paradox: The Art of Political Decision Making, W.W. Norton.

Stölting E. and Schimank U. (eds) (2002): Die Krise der Universitäten, Opladen, Westdeutscher Verlag.

Schwarz, S. and Westerheijden D. (2004): Accreditation and Evaluation in the European Higher Education Area, Dordrecht/Boston/London, Kluwer Academic Publishers.

Shattock M. (1999): "Governance and Management in Universities: the way we live now", Journal of Educational Policy, 14, pp. 271-282.

Swaan (de), A. (1988): In Care of the State : health care, education, and welfare in Europe and the USA in the modern era, New York : Oxford University Press, 1988

Teichler U. (2005a): Hochschulstrukturen im Umbruch. Eine Bilanz der Reformdynamik seit vier Jahrzehnten, Francfort and New York, Campus Verlag. 
Teichler U. (2005b): Hochschulsysteme und Hochschulpolitik. Quantitative und strukturelle Dynamiken, Differenzierungen und der Bologna-Prozess, Münster, Waxmann.

Van der Meulen B. (1998): "Science Policies as Principal-agents games. Institutionalizationa and path dependency in the relation between government and science », Research Policy, 27, pp. 397-414.

Van Vught, F. (1995) : Policy Models and Policy Instruments in Higher Education : the Effects of Governmental Policy-making on the Innovative Behaviour of Higher Education Institutions, Vienne, Institut für Hohere Studien, Series $n^{\circ} 26$.

Van Vught, F. (ed) (1989) : Governmental Strategies and Innovation in Higher Education, Higher Education Policy Series n7, London, Jessica Kingsley Publishers.

Witte J. (2006): Change of degrees and Degrees of Change. Comparing Adaptations of European Higher Education Systems in the Context of the Bologna Process, Doctoral thesis, CHEPS, University of Twente. 